\title{
Dermatology Research
}

\section{Nevus Sebaceous of Jadassohn in a 13 Years Old Patient: Case Report}

\author{
Hugo Romero Alvarenga ${ }^{1 *}$, Nadia Irias Funez ${ }^{2}$ and Yester Sierra Benitez ${ }^{3}$
}

${ }^{1}$ Cirujano Oral y Maxilofacial, UNAM, Cuidad de Mexico, Mexico. Jefe del Servicio de Cirugia Oral y Maxilofacial del Hospital Escuela, Tegucigalpa, Honduras, Profesor Adjunto UNAH Y UNICAH, Honduras.

${ }^{2}$ Cirujano Oral y Maxilofacial, Universidad del Bosque, Bogota, Colombia. Profesor adjunto UNAH y UNITEC, Tegucigalpa, Honduras.

${ }^{3}$ Cirujano Dentista Infieri UNAH, Servicio de Cirugia Oral y Maxilofacial, Hospital Escuela, Tegucigalpa, Honduras.

\section{*Correspondence:}

Cirujano Oral y Maxilofacial, UNAM, Cuidad de Mexico, Mexico. Jefe del Servicio de Cirugia Oral y Maxilofacial del Hospital Escuela, Tegucigalpa, Honduras, Profesor Adjunto UNAH Y UNICAH, Honduras, E-mail: cmfalvarenga@gmail.com.

Received: 16 December 2019; Accepted: 08 January 2020

Citation: Hugo Romero Alvarenga, Nadia Irias Funez, Yester Sierra Benitez. Nevus Sebaceous of Jadassohn in a 13 Years Old Patient: Case Report. Dermatol Res. 2020; 2(1); 1-3.

ABSTRACT
One patient with sebaceous nevus of Jadassohn is presented. This lesion is considered a hamartoma, because it is
caused by benign hyperplasia of sebaceous glands. Most common location is on the scalp and less frequently on
the face, trunk and extremities, with a low risk to malignant neoplasia. The lesion may appear from birth. When
patients get to puberty, develop into different kinds of tumors. Treatment is surgical excision along prepuberal age.

\section{Keywords}

Lesion, Nevus sebaceous, Dermatologist, Scalp, Surgery.

\section{Introduction}

Nevus sebaceous was first described by the German Dermatologist Jadassohn in 1895. It is a hamartoma, which affects all components of the skin except the eccrine glands. It is present at birth, most commonly on the skin of the scalp, next to on the face and neck, much less frequently on other parts of the body [1]. It occurs in approximately 1 in 1000 live births [2]. Its usually presents as a verrucous, granulated, yellow - orange plaque that may be round, crescentic or linear in shape [3].

Nevus Sebaceous tend to change over time, particularly during puberty, when the skin can become more raised, verrucous and greasy because of sebaceous gland hormone stimulation [4]. Histologically a nevus sebaceous is characterized by papillomatous hyperplasia of the epidermis and sebaceous glands. Sometimes this lesion is precursor of malignant tumors [5]. The timing of excision is also a matter of debate; with some advocating early excision and others suggesting that delayed excision is reasonable [6]. We describe the case of a 13-year-old boy diagnosed with Nevus Sebaceous of Jadassohn.

\section{Case Report}

A 13-year-old male patient, in excellent health. Presenting with a high, asymptomatic, well-defined, brown color lesion, located in the mandibular symphysis, with a history of evolution from birth according to the mother's story. At the specified clinical evaluation, an expansion of the same neck injury, at the height of the Hyoid Bone, of white palpation resistance, with a rough surface was evaluated.

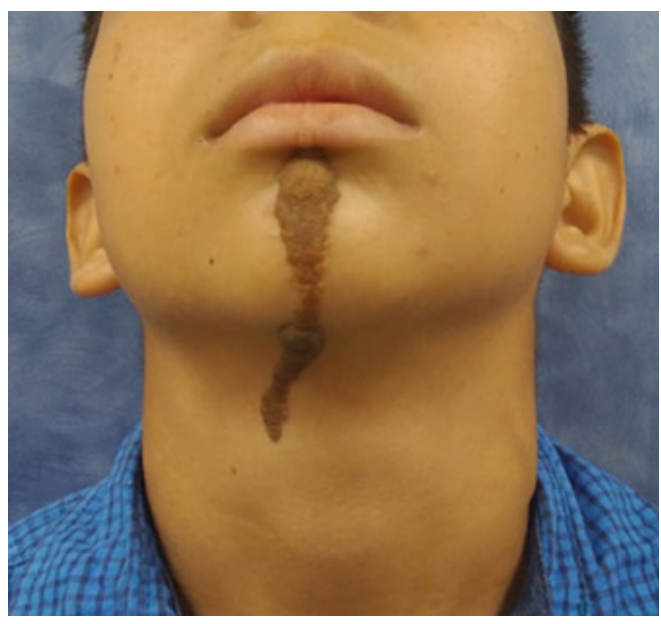

Figure 1: Initial Extraoral Photography. 
In the intraoral level, alteration of the oral mucosa was observed and presumed relationship with the dental organ 3.1. In addition fever, suppuration or presence of any other liquid was discarded. An orthopantography was requested to rule out a relationship with hard tissues, no radiological characteristics were observed that could correlate this theory.

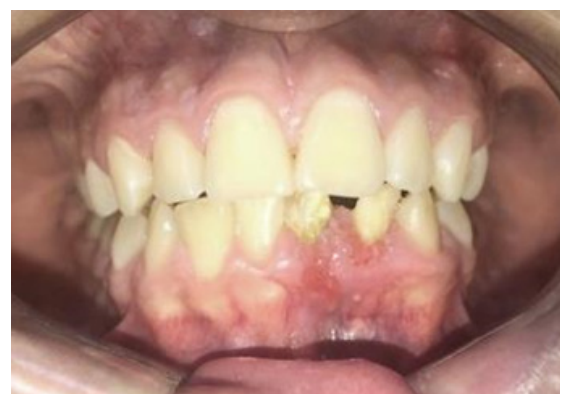

Figure 2: Intraoral Photography.

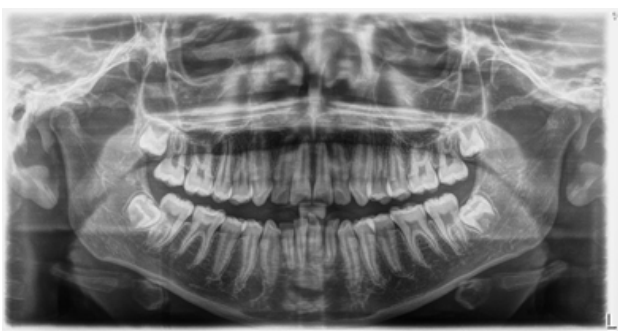

Figure 3: Orthopantography.

An incisional biopsy of the lesion was performed, we send two irregulars of tissue fragments, the bigger mid- $0.5 \times 0.3 \times 2.0 \mathrm{~cm}$ and the smaller mid- $0.3 \times 0.2 \times 0.1 \mathrm{~cm}$ resulting in Jadahhson's Nevus Sebaceous. It was programmed to perform the surgical intervention under general anesthesia, we performed the complete removal of the lesion and an excisional biopsy was realized, wound was sutured with Nylon and Vicryl. He complied with antibiotic coverage and no complications were raised.
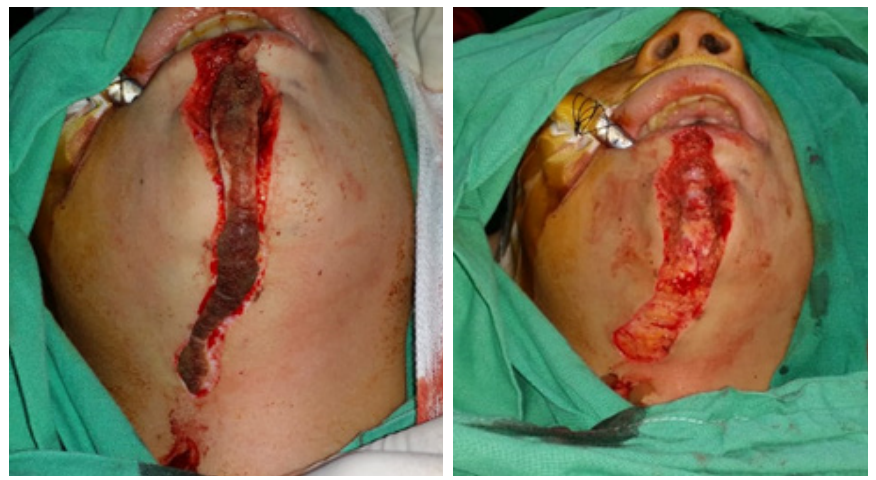

Figures 4 and 5: Intraoperative Photography. Intraoperative Photography.

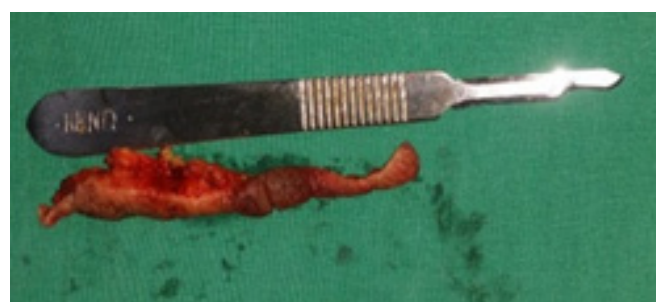

Figure 6: Size Comparison with a scapel.

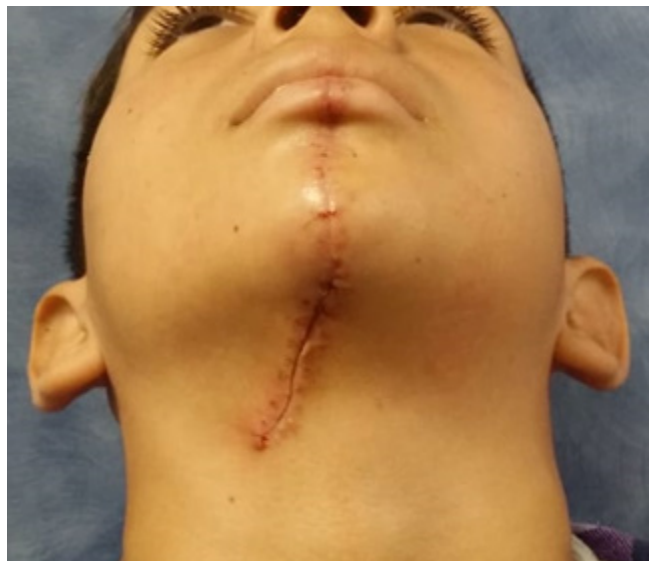

Figure 7: Post-operative control Photo.

\section{Discussion}

Nevus sebaceous can be defined as a hamartoma, representing an organizational or embryogenic defect resulting in an abnormal mixture of tissue of varying types [7]. Reported incidence of $0.05 \%$ to $1 \%$ of dermatology patients [6]. Can reach a diameter of $10 \mathrm{~cm}$ and develops in three stages. The first stage, ranging from the birth to childhood is characterized by a flat lesion with a soft surface at touch and yellowish - pink coloration, remaining unchanged due to quiescence of the sebaceous glands. With the onset of adolescence comes the second stage, when the lesion becomes vegetating and mamillonated with an increase in thickness due to hormonal influence on the sebaceous and apocrine glands. The third stage occurring in about 20 percent of the cases, usually develops after the 40 years, and emergence of tumors such as trichoblastoma, syringocystadenoma papilliferum and trichilemmoma might occur [5].

Studies have reported more than 40 different kinds of secondary neoplasm [6]. Trichoblastoma (34.7\%), syringocystadenoma papilliferum (24.7\%), apocrine adenoma (10\%) and trichilemmoma $(5.3 \%)$ are the most common secondary neoplasm found within NSJ [8].

Malignant tumors were identified in $0.8-3.5 \%$ of nevi, mainly in adult patients, with basal cell carcinoma being the most common. Their incidence increases with the age, and malignant growths have not been observed before the age of 10 years [1] in our case the Patient has 13 years old.

The molecular basis for carcinogenesis in nevus sebaceous remains unknown, but deletions in the tumor suppressor PTCH gene seems to enhance the neoplastic potential of the hamartoma. For that reason, Nevus Sebaceous is considered to be a precancerous lesion; the most common benign neoplasm arising in a nevus sebaceous is the syringocystadenoma papilliferum, whereas the most common malignant neoplasm is the basal cell carcinoma [2].

As for the treatment, removal surgery is recommended in the prepubertal stage, because of its potential malignant transformation and because the nevus is not yet fully developed and the skin is 
more moldable, achieving an aesthetic healing [9]. Alternative treatment modalities options include photodynamic therapy, $\mathrm{CO}_{2}$ laser, and dermabrasion [5]. Reconstruction with grafts is sometimes necessary due to tissue loss, but this was not necessary in our patient. Is important the follow up for the circumscript ampliation, ulceration or appearance of exophytic nodule they should raise the suspicion of malignant transformation, although benign accidents are more frequent [10].

\section{Conclusion}

The others treatments modalities do not completely eliminate the lesion, we recommend the surgical excision.

This lesion has a low probability of being malignant, but despite being able to diagnose it clinically, we need to be able to confirm that diagnosis through a biopsy.

\section{References}

1. Abe S, Yamamoto Y, Uno S, et al. Malignant melanoma arising in a sebaceous nevus of the scalp. British Journal of Plastic Surgery. 2003; 56: 171-173.

2. Alfaro-Sánchez AB, Zaldívar-Leal F, Casados-Vergara RF, et al. Nevo sebáceo de Jadassohn asociado con carcinoma basocelular. Dermatol Rev Mex. 2014; 58: 295-299

3. Bruna Paninson. Basal Cell Carcinoma on a Nevus Sebaceous of Jadassohn. Journal of Clinicañ and Aesthetic Dermatology. 2019; 12: 40-43.

4. Watson I. T, DeCrescenzo A, Paek S. Y. Basal cell carcinoma within nevus sebaceous of the trunk. Baylor University Medical Center Proceedings. 2019; 32: 392-393.

5. Niemczyk E, Niemczyk K, Małdyk J, et al. Ceruminous adenoma (ceruminoma) arising in a nevus sebaceus of Jadassohn within the external auditory canal of a 3 yearold boy - A case report. International Journal of Pediatric Otorhinolaryngology. 2015; 79: 1932-1934.

6. Idriss M. H, Elston D. M. Secondary neoplasms associated with nevus sebaceus of Jadassohn: A study of 707 cases. Journal of the American Academy of Dermatology. 2014; 70 : 332-337.

7. Eisen D. B, Michael D. J. Sebaceous lesions and their associated syndromes: Part I. Journal of the American Academy of Dermatology. 2009; 61: 549-560.

8. Rizzo R, Pavone P. Nevus Sebaceous and Its Association with Neurologic Involvement. Seminars in Pediatric Neurology. 2015; 22: 302-309.

9. Moreno Alonso de Celada R, Floristán Muruzábal U, De Lucas Laguna R. Nevo sebáceo de Jadassohn. Anales de Pediatría. 2009; 70: 391.

10. Liancapi VP, Paiva MO. Nevo sebáceo de Jadazon. Revista chilena de pediatría. 1996; 67; 84-86. 